\title{
THE DOUBLE WAVE \\ OF GERMAN AND JEWISH NATIONALISM: MARTIN BUBER'S INTELLECTUAL CONVERSION ${ }^{1}$
}

\author{
PETER ŠAJDA
}

\begin{abstract}
The paper provides an analysis of Martin Buber's intellectual conversion and shows how it facilitates a deeper understanding of the phenomenon of nationalism. Buber, who is today known mainly as a key representative of dialogical philosophy, was in the 1910s part of the double wave of German and Jewish nationalism which strongly affected the German-speaking Jewish public. Buber provided intellectual support for this wave of nationalism and interpreted World War I as a unique chance for the spiritual unification of European Jewry. Consequent to his conflict with Gustav Landauer Buber underwent a complex intellectual and existential transformation. He abandoned key concepts of his pre-dialogical thought and laid the foundations of his dialogical thought. He rejected his endorsement of Geman nationalism and substantially reevaluated his political positions. The analysis of Buber's intellectual development sheds light on some important aspects of the dynamics of nationalism.
\end{abstract}

Keywords: nationalism; national identity; kinetic community; dialogical philosophy; war; JewishGerman relations

\section{Introduction}

In recent years we have seen a rise of nationalism in various parts of the world. Europe is no exception, it has witnessed the strengthening of nationalist movements throughout the continent. Especially following the European migrant crisis of 2015 the issue of national identity has become prominent in political and cultural debates. In this paper I analyze the intellectual conversion of the Jewish philosopher Martin Buber (1878-1965) which took place at a time when a series of waves of nationalism swept across Europe. Today Buber is known primarily as a leading representative of dialogical philosophy which focuses on interpersonal relations. It is less known that in the 1910s he was part of the double wave of German and Jewish nationalism which strongly affected the German-speaking Jewish public. Buber was enthusiastic about Germany's entry into World War I and saw the war as a unique

\footnotetext{
1 This work was produced at the Department of Philosophy, Faculty of Arts of Trnava University as part of the VEGA project no. 1/0871/18.
}

DE GRUYTER 
chance for strengthening the sense of community among European Jews. In 1916, however, he began to reconsider this view and subsequently rejected it. This intellectual development was accompanied by a restructuring of the foundations of his philosophy. I aim to provide an analysis of this profound transformation and show how it facilitates a deeper understanding of the phenomenon of nationalism. I find Buber's intellectual conversion interesting especially in three respects. First, it was his most complex existential transformation and the climax of a series of political, philosophical and relational crises in his life. Second, it represents a watershed in his thinking, as he abandons key concepts of his pre-dialogical thought and lays the foundations of his dialogical thought. Third, it occured in the context of the double wave of German and Jewish nationalism, which is an intriguing phenomenon that appears as an oxymoron to the post-Shoah generations. The analysis of Buber's conversion can inspire intellectuals today as they reflect on different forms of nationalism that intertwine, enhance or negate each other.

\section{Buber's nationalism and the concept of a kinetic community}

As Paul Mendes-Flohr pointed out in his article "Martin Buber as a Habsburg Intellectual" Buber was not a Yekke-a monocultural German Jew-but a $k$. und $k$. Jude - a polycultural Austro-Hungarian Jew (Mendes-Flohr, 2006, p. 13, p. 24). Buber was born in Vienna, but grew up in Galicia in his grandparents' home. He spoke Yiddish and German with his grandparents and Polish at the gymnasium he attended in Lemberg (Lviv). His first works appeared in 1897 in a Warsaw weekly and were written in Polish (Cohn \& Buber, 1980, p. 13). For his university studies he moved to Vienna and later to Germany and Switzerland. In 1906 Buber settled in Berlin and subsequently in Heppenheim in Hesse, where he lived until his emigration to Palestine in 1938. Despite his colorful cultural and linguistic background during the first half of World War I Buber identified strongly with German nationalism and with the form of Jewish nationalism that was inspired by it.

In what follows I focus on the period of 1914-16 in which Buber's involvement in the double wave of German and Jewish nationalism peaked and then abruptly abated. His involvement in both streams of nationalism had initially a pronounced militarist component. Paradoxically, shortly before the outbreak of the war Buber took part in an international peace initiative known as the Forte Circle. This group of eight intellectuals-five Germans, two Dutchmen and a Swede-met in Potsdam in June 1914 "drawn together by some undefined presentiment of catastrophe" (Friedman, 1991, p. 75). Their aim was to bring together intellectuals from different countries in order to undertake a joint effort to avert a conflict between European nations. However, the outbreak of the war in the summer of 1914 prevented the group from further meetings and caused a deep rift that led to its disintegration. The members disagreed on the interpretation of the war events and accused each other of misleading the public in their writings.

Buber sided with those members of the group who refused to dismiss the war as illegitimate. ${ }^{2}$ He defended German and Austro-Hungarian war actions and applauded what

\footnotetext{
2 See especially his correspondence with the German member of the circle Christian Florens Rang (1864-1924). Rang's letter from September 18, 1914 presents analogous ideas to those included in
} 
he saw as the new inner unity of both the German and the Jewish people. His positive view of the war is perhaps best expressed in his letter to Hans Kohn from September 30, 1914. In this letter Buber describes the enthusiasm of large parts of the German population for the common cause of the war and expresses his regret at being denied the opportunity to join the army:

Never has the concept of 'nation' become such a reality to me as it has during these weeks. Among the Jews, too, the prevailing feeling is one of solemn exaltation. Among the millions who volunteered were Karl Wolfskehl and Friedrich Gundolf... I myself unfortunately have not the slightest prospect of being utilized; but I am trying to help in my own way. In conjunction with the Jewish socialists of Germany...I have begun organizing some activity in Poland. (Buber 1972-75, vol. 1, pp. 370-1, Buber, 1996, p. 160)

Buber endorsed fully the German and Austro-Hungarian military offensive and called for an unreserved participation of the whole German nation. He describes the war in symbolic terms, drawing on motifs from the Bible and Dante. He promotes the ideal of self-sacrifice for a greater cause and claims that the present moment marks the beginning of a new era:

I hope that German-Austrian victories will soon provide us with the opportunity to extend this work; although I am not permitted to go to the front, I should like to be active in the vicinity of it. To everyone who would like to save himself in these times, the words of the Gospel of John apply: 'He who loves his life loses it'... If we Jews could really feel, feel through and through, what this means to us: that we no longer need our old motto, Not by might, but by spirit, since power and spirit are now going to become one. Incipit vita nova. (Buber 1972-75, vol. 1, p. 371, Buber, 1996, p. 160)

A diametrically different view of the war was presented by the Dutch member of the Forte Circle, Frederik van Eeden (1860-1932). He criticized Germany's military aggression against its western neighbors and the German intellectuals' complicit attitude in his "Open Letter to Our German Friends," which appeared in De Amsterdammer, as well as in two letters addressed to the members of the Forte Circle (Friedman, 1991, p. 86). Buber reacted to Van Eeden's criticism both in private correspondence and in a journal article. He wrote a long letter to Van Eeden, parts of which he published in Der Neue Merkur under the title "Bewegung. Aus einem Brief an einen Holländer" [Movement. From a letter to a Dutchman] (1915). In the letter Buber reproaches Van Eeden for disseminanting half-truths about German political and military actions and argues that the German invasion of Belgium was prompted by the latter's anti-German alliance with France and Britain. He criticizes Van Eeden for one-sidedness, maintaining that atrocities were committed by both sides of the conflict, as evidenced by the torture of wounded German soldiers by Belgian civilians (Buber 1972-75, vol. 1, p. 375). Buber acknowledged that the German press engaged in a virulent propaganda against Germany's adversaries, but he discerned a similar phenomenon in the British and French mass media. Above all, he denounces Van Eeden's claim that the anti-

Buber's "Bewegung. Aus einem Brief an einen Holländer." Rang underwent a similar intellectual conversion as Buber (Brody, 2018, p. 83).

3 Translation slightly modified. 
German alliance is in a position of moral superiority. This claim is absurd, as the alliance unites free countries, such as Britain and France, with the despotic Russian Empire (Buber 1972-75, vol. 1, pp. 375-6). This perspective legitimizes Russia's repressive policies, which it deploys also against its own population. Since Russia can only be transformed with help from outside, German victory could become a crucial impulse for its liberation movements.

Buber continued his polemic in "Bewegung. Aus einem Brief an einen Holländer" [Movement. From a letter to a Dutchman]. in which he dismissed Van Eeden's interpretation of German war enthusiasm as mass manipulation and presented his own interpretation of the atmosphere in Germany. He views the popular support for the war as a result of free decisions of individuals who are united by their belief in "an absolute value" for which they are willing to sacrifice even their lives (Buber, 1915, p. 489, p. 491). ${ }^{4}$ Such belief and willingness can be found not only in Germany but in every nation in which individuals relate to the absolute by resolutely realizing their convictions. Buber calls this translation of belief into action kinesis (Bewegung) and claims that the absolute manifests itself in it. While avoiding a definition of the absolute - to which he attributes religious characteristics ${ }^{5}$ - he argues that for those passionately involved in the service of their country the fatherland is the "visible, accessible, graspable form of the absolute" (Buber, 1915, p. 491). ${ }^{6}$ The lives of these "decisive" individuals are marked by kinesis, which is absent from the lives of those merely "passing by" (Buber, 1915, p. 490). Thus, the basic source of unity is not the individuals' beliefs but their effort to realize them. The intensity of committed service connects them regardless of which country they fight for. They are united by virtue of the fact that they fight with "the same intensity, sincerity and directness" (Buber, 1915, p. 490). They may struggle to achieve mutually opposed objectives; nonetheless what is crucial is that they each fight with utmost commitment, which sets them apart even from their countrymen who do not share in this lived experience (Erlebnis). The kinetic community of committed individuals represents a positive aspect of the war, which Van Eeden completely disregards.

As Paul Mendes-Flohr and Martin Jay pointed out, Buber's description of the kinetic community of committed fighters is rooted in his theory of Erlebnismystik (Mendes-Flohr, 1978, p. 131; Jay, 2005, p. 126). Buber's earlier studies on mysticism and ecstasy made a clear distinction between Erfahrung and Erlebnis with the latter referring to the mystic's lived experience that defied psychological, physiological or other causal explanation (Buber, 1909, p. V). Buber identified in this lived experience a moment of limitlessness and unity with others, which was not sociological but psychological (Buber, 1909, pp. XVIII-XIX). This lived experience facilitated inner community with others despite the fact that it took place in the private sphere. Buber later applied the notion of inner community to those who shared in a crucial existential Erlebnis. In the course of World War I he applied this concept of community first to those passionately serving their fatherland and later to the Jewish soldiers, irrespective of the country they served, fighting out of the sense of a paramount duty.

\footnotetext{
4 For a detailed analysis of Buber's pre-dialogical doctrine of unity and its impact on his interpretation of the war see (Mendes-Flohr, 1978, pp. 68-77, pp. 131-5).

5 The religious aspect of Buber's intellectual conversion and his later polemic against apolitical religion is examined in (Šajda, 2013).

6 Unless otherwise indicated, the translations are my own.
} 
The outburst of German nationalism, which was supported by a number of Jewish intellectuals, became a source of inspiration for Jewish nationalism. This can be seen, for example, in the role that Johann Gottlieb Fichte's Addresses to the German Nation (1808) played in Jewish circles. This work, which aims to strengthen German national identity, became popular with Jewish thinkers and activists. Buber included it in his list of ten books which he recommended to the readers of Wiener Kunst- und Buchschau at Christmas 1914 for a deeper understanding of "the German war" (Buber 2001ff., vol. 1, pp. 279-80). He saw Fichte's idea of Germanness as a task as relevant for the Jews who struggled with the issue of their national identity (Buber 2001ff., vol. 1, p. 289). Shmuel Hugo Bergmann wrote to Buber in May 1915 that Fichte played a crucial role in the formation of contemporary Jewish identity, as he inspired Jewish intellectuals to rediscover their roots. Bergmann even claimed that "[o]nly because we had Fichte could we find the parallel streams in Jewish culture. We learned how to understand Judaism .... It is only as Germans that we can enter the life of Jewish culture" (Buber 1972-75, vol. 1, pp. 388-9, Shapira, 1999, p. 91). In a similar vein, Siegfried Lehmann wrote to Buber in October 1915 describing Fichte's impact on the Jewish youth movement. Jewish students at German universities sought to revive Jewish national consciousness by implementing Fichte's ideal of national education (Buber 1972-75, vol. 1, pp. 401-2).

As the situation of the Jews differed markedly from the situation of the Germans, also their nationalism had a different character. This is even more so for Buber, who refused to envision the Jewish renewal in merely political terms. Although he distanced himself from the common use of the term nationalism, he applied it nonetheless to the contemporary Jewish striving for unity, freedom and emancipation (Buber, 1920, p. 100). He did not hesitate to call himself a Jewish nationalist and hoped for a collaboration with like-minded individuals from other nations (Buber, 1920, p. 100). It is obvious from his pre-war writings that his vision of Jewish renewal focused on a much broader horizon than just an achievement of political goals. ${ }^{7} \mathrm{He}$ addressed the call for a rediscovery of Jewish identity to every Jewish individual prompting him to existential transformation that would form the basis for the transformation of the entire Jewish community (Buber 1911, pp. 70-75, pp. 99102). Buber's view of Jewish renewal, however, contained also political components and was influenced by political events. He saw World War I as an opportunity to strengthen the bonds between the Jews in Europe and expressed his hope for a new kind of Jewish emancipation after the February Revolution in Russia (Buber, 1920, p. 102).

Buber applied the idea of a kinetic community to the European Jews in his essay Die Losung (1916). He acknowledged the war's tragic consequences for the Jews but once again he highlighted its unifying effect. With regard to the situation of the Jews he pointed out that although outwardly they find themselves in a state of utter fragmentation inwardly a new unity has emerged in the chaos of the war:

Hundreds of thousands of Jews fight against each other; but the decisive thing is: they do not fight out of compulsion, but out of the sense of a paramount duty...They give their utmost, and their innermost, too. (Buber, 1916a, p. 1)

7 I thank the anonymous reviewer who emphasized this point. 
Jews passionately involved in the service of the fatherland are part of a "great and vital community" united by kinesis (Buber, 1916a, p. 1). This unity is all the more important, as European Jewry has been plagued by atomization and loss of identity. Especially in the West, the Jews lost the connection with their roots and traditions and became absorbed in the pursuit of their private lives. As a consequense, atomization and assimilation were widespread (Buber, 1916a, p. 1). With the advent of the war the Jews were summoned by the fatherland to fight for a common cause and were drawn into "the great life of community" (Buber, 1916a, p. 2). Buber believes that the newly recovered sense of community will help the Jews reconnect also with the "deep community of their blood and kind" (Buber, 1916a, p. 2). He reports that all the Jewish soldiers returning from the front, whom he personally met, had strengthened their Jewish identity and their sense of responsibility for the fate of their people. Moreover, the Jewish people have a special mission among the nations of the world. They do not represent merely a nationality alongside other nationalities, for they cannot be satisfied just by serving their own interests. Their ultimate vocation is to forge a fraternal, spiritual bond between nations. Buber believes that this "function of connecting nations" (Buber, 1916a, p. 3) can only be realized if the Jews are deeply rooted in their own identity and have found their place in the world.

\section{Landauer's protest as an impetus for Buber's Dialogical Turn}

A crucial impetus for Buber's reevaluation of his view of the war was his conflict with Gustav Landauer (1870-1919). The two were close friends, both were Jewish authors writing in German and members of the Forte Circle. They frequently discussed each other's texts and when Buber launched the monthly Der Jude in 1916 he invited Landauer to become a contributor. ${ }^{8}$ Landauer was, however, scandalized by Buber's Die Losung which was the leading article of the journal's first issue. Landauer was equally critical of Buber's Der Geist des Orients und das Judentum [The spirit of the Orient and Judaism] which also appeared in 1916. In the latter Buber called for a new era of collaboration between the German and the Jewish people in bridging the divide between the West and the East. He suggested that the German nation should take upon itself the role of the leading representative of the West in initiating new ways of understanding and cooperation with the East. In this endeavor the Jews could serve as intermediaries since they have preserved cultural traditions formed in the East but have also absorbed and shaped western cultural traditions. The two peoples are already closely connected, as from among the European nations the Germans have had the strongest impact on the Jewish culture and within Europe Jewish influence has been most intensive in the German-speaking cultural milieu (Buber, 1916b, p. 11, pp. 46-8).

Landauer voiced his deep disappointment with Buber's essays in his letter from May 12, 1916. He argues that they pursue identical ideological line and declares that they "are very painful to me, very repugnant, and border on incomprehensibility" (Buber 1972-75, vol. 1, p. 434, Buber, 1996, p. 189). He had to discontinue his reading of Der Geist des Orients

\footnotetext{
8 Buber formulated a short description of the journal's orientation in the letter to Franz Rosenzweig from November 11, 1915 (Buber 1972-75, vol. 1, p. 404). Landauer was originally open for the collaboration and sent Buber a contribution (Buber 1972-75, vol. 1, p. 413-15).
} 
und das Judentum [The spirit of the Orient and Judaism] because his "blood boils" when he reads Buber's exaltation of contemporary Germany (Buber 1972-75, vol. 1, p. 434, Buber, 1996, p. 189). Buber paints a distorted picture of reality when he describes Germany's role in European politics and culture without ever mentioning its imperialism. His "aesthetic" presentation of Germany as a "redeemer nation" turns a blind eye to German colonization overseas and expansionist war in Europe (Buber 1972-75, vol. 1, pp. 434-5, Buber, 1996, p. 189). Buber had become a German propagandist with views in line with the official political doctrine.

Landauer further argued that although Die Losung provides a more complex view of contemporary developments than the doctrinaire Der Geist des Orients und das Judentum [The spirit of the Orient and Judaism] it also relies on oversimplifications. Buber's claim that hundreds of thousands of Jews dispersed in the armies of the continent fight solely out of the sense of a paramount duty is implausible given the much more complicated situation on the ground. Buber is

disavowing the thousands and tens of thousands of poor devils who are not at all conscious of a mission but are indeed submitting to compulsion out of a paramount duty (namely, to live), because by so doing they can hope they will be more likely to come out alive. (Buber 1972-75, vol. 1, pp. 435-6, Buber, 1996, p. 190)

Buber's idealistic description of the war exalts the metaphysical kinetic community of Jewish fighters but pays no attention to those who do not share the war enthusiasm. Landauer points to this blind spot, as Buber claims to speak in the name of all Jewish soldiers: "In this passage you undertake to describe the average Jew, and is there not a single ordinary person in this psychology of yours?" (Buber 1972-75, vol. 1, p. 436, Buber, 1996, p. 190) Buber ignores the widespread sense of helplessness and meaninglessness among those soldiers who are forced to participate in a overwhelming human tragedy that is not at all in their interest.

Landauer's key philosophical argument that substantially contributed to Buber's dialogical turn is that Buber's interpretation of the war subordinates concrete historical relations to metaphysical ones. The metaphysical community of committed soldiers, most of whom never encounter each other, is at the center of Buber's interpretation while the concrete community of the individual soldier and his family is marginal. The metaphysical bonds of intense passion and sense of duty supersede interpersonal bonds that connect the soldier with his wife and children. Landauer sees this hierarchization as a "lifeless construct" which denies basic existential realities (Buber 1972-75, vol. 1, p. 436, Buber, 1996, p. 190). He suggests that the bonds between individuals based on real life encounters, shared experiences and exchange of emotions are the most determining factors in individuals' lives. Since the articles published in Der Jude set the loyalty to the nationalist agenda of the Habsburgs and the Hohenzollern over the loyalty to one's own family and friends-and ignore the tragedy of Jews killings Jews-Landauer cannot imagine a collaboration with the journal. He also admonishes Buber that after the war he will have hard time explaining his stances (Buber 1972-75, 1, p. 437, Buber, 1996, p. 191).

Although Buber's immediate reaction to Landauer's letter is not known, his subsequent development proves that it affected him profoundly. The Buber biographers and scholars Maurice Friedman, Hans Kohn and Paul Mendes-Flohr agree that following the conflict 
with Landauer Buber experienced an intellectual breakthrough that led to his development of dialogical thinking. He incorporated key elements of Landauer's critique into this new way of thinking. Buber's reevalution of the positions criticized by Landauer is confirmed also by three practical steps he took after the conflict (Mendes-Flohr 1978, pp. 139-40): First, in later editions of Der Geist des Orients und das Judentum [The spirit of the Orient and Judaism] he deleted the criticized passages and reformulated those in which he had exhorted the German nation to become the leading representative of the West in relations with the East. He acknowledged that the German nation did not fulfil this mission and can no longer aspire to do so. It is now the task of Europe as a whole (Buber, 1921, p. 7). Second, after Landauer's death in 1919-when he was killed during the overthrow of the Bavarian Soviet Republic, which he briefly represented-Buber was appointed the administrator of his Nachlass. He made sure that the letter from May 12, 1916 was not included in the published edition of Landauer's correspondence. Third, then collaborating with Hans Kohn on his biography Buber avoided a closer discussion of his conflicts with Van Eeden and Landauer and of his nationalist enthusiasm expressed in the letters to Kohn.

Buber stated in 1957 that he wrote the first outline of his dialogical manifesto Ich und $D u$ [I and Thou] in 1916 (Buber, 1984, p. 122; Horwitz, 1978, p. 155). Although the early drafts do not contain a full-fledged dialogical terminology yet, it is clear that his thinking has undergone a reorientation. Buber's dialogical project shifts the emphasis from subjectivity to intersubjectivity, from a metaphysical community to an interpersonal community, and from a private experience of God to an interhuman experience of God. Although Buber continues to be interested in the processes of subjectivity his new point of departure is relation. The basic principle of his dialogical philosophy is that "[i]n the beginning is relation" (Buber, 1923, p. 25, Buber, 1937, p. 18). Relation is the primal human reality, which is antecedent to the consciousness of the separate individual $I$. Human life begins as I-Thou and only later the I sets itself apart from the relation: "Through the Thou a man becomes $I$ " (Buber, 1923, p. 36, Buber, 1937, p. 28). In the broader context of a community Buber sees the I-Thou relation as a fundamental building block of an authentic We. This relation involves a concrete counterpart and is characterized by directness, immediacy and mutuality, ${ }^{9}$ and thus differs markedly from the largely anonymous metaphysical relation of shared kinesis promoted in the pre-dialogical writings. The dialogical concept of a God-relation presupposes God's presence in dialogical relations between humans: "In each Thou we address the eternal Thou" (Buber, 1923, p. 13, Buber, 1937, p. 6). The personal God of dialogical philosophy has little in common with the indeterminate absolute which manifests itself in the process of individual kinesis. Buber integrates the God-relation into the sphere of interpersonal relationality already in Der Heilige Weg [The Holy Way] (1920) and in the lecture series Religion als Gegenwart [Religion as Presence] (1922) which formed the basis for Ich und Du [I and Thou].

There is also an obvious change in Buber's understanding of nationalism after 1916. Although he does not discard the concept of a unique national destinty, he claims that a new kind of nationalism is taking root across Europe. Its aim is not to prevail but to shape and

9 For an analysis of Buber's notion of mutuality in dialogical relations see (Bizoň, 2017). 
it is oriented toward collaboration among nations rather than toward political and military confrontation (Buber, 1920, p. 100).

Buber's change of heart concerning the interpretation of the war was strengthened by the developments on the German political scene which showed signs of increasing antisemitism. In October 1916 the Prussian minister of war Adolf Wild von Hohenborn promulgated the Judenzählung, whose aim was to determine the measure of Jewish participation in the German army. The census was prompted by accusations that the Jews were exempt from military duty in a disproportionate measure. The results of the census were not published which only increased the suspicion of insufficient patriotism on the part of the German Jews. Buber was outraged by the census and protested against it in Der Jude:

We are used to being counted. Russia counts our children in its schools and Poland our workers in its communal enterprises: to see if they are not too many. On the other hand, a German student union requested some months ago that our fallen on German battlefields be counted. They believed there were not enough of them. (Buber, 1916c, p. 564)

More than two decades later-when state-sponsored antisemitism in Germany reached new highs-Buber returned to the topic of Jewish-German relations. In the essay entitled Das Ende der deutsch-jüdischen Symbiose [The end of the German-Jewish symbiosis] he spoke of a total collapse of Jewish hopes for a meaningful symbiosis with the German nation. Looking at the past he observed-with a self-critical echo- that "many excellent Jewish men devoted themselves to Germanness in an overly unreserved way" (Buber, 1993, p. 152).

\section{The dynamics of nationalism in light of Buber's conversion}

The analysis of Buber's intellectual conversion can contribute to the understanding of the phenomenon of nationalism in at least three ways.

First, it shows how historical circumstances enable a combination of waves of nationalism that is unimaginable in other historical situations. Buber and other Jewish intellectuals highlighted the fact that the contemporary western and central European Jewry found itself in a state of rootlessness and atomization. The abandonment of distinctive elements of Jewish life and identity-building practices led to a weakening of community ties and excessive individualism. The Jews became increasingly alienated from their traditions and sources of common identity. Simultaneously, they participated in German public life which became an important point of reference and a partial substitute for the lost connections with the Jewish world. The surge of German nationalism after the outbreak of World War I included a call for national unity in the struggle for a common cause. This call appealed to those Jews who sought to overcome the centrifugal tendencies of modern society and welcomed the chance to prove themselves as German patriots. They supported the German war effort in different ways including voluntary enlisting, social activism and intellectual advocacy. The galvanizing effect of German nationalism prompted numerous Jewish individuals and groups to address the issue of their Jewish identity. They used the sources of German national awakening — such as Fichte's Addresses to the German Nation - for the purposes of a Jewish revival and began to explore more intensively their own cultural heritage. They tried to create a similar sense of unity among the Jews as 
the one they experienced among the Germans. Such unity-often connected to military experience-seemed an efficient antidote to the rampant atomization. Thus, the Jews saw their participation in the wave of German nationalism as a preparation for the wave of Jewish nationalism that would strengthen their slack ties within Germany or even Europe. They saw the positive side of the war in its unifying effect and therefore rejected purely negative interpretations of the war. As we have seen in Buber's case, this easily led to an embracing of German war propaganda and one-sided stances in the heavily polarized political discourse.

Second, the analysis elucidates some factors that led to the disintegration of the double wave of nationalism. As Landauer pointed out, the German war could never become the Jewish war, because the Jews were conscripted into all the armies of the continent and were called to kill each other. This tragic existential contradiction of Jewish self-annihilation was too obvious and could not be disproved by any positive interpretations of the war. Thus, the positive moment of Jewish national revival was heavily outweighed by the horrible absurdity of Jews fighting on both sides of the front. For this reason the Jews who claimed that the war was in the Jewish interest appeared as disingenuous advocates of German imperialism. The suffering of the ordinary Jewish soldier who did not identify with the German war and saw it as a great human tragedy became a strong argument in the hands of the opponents of the war. The war broke up the unity of the nuclear family which was the most basic form of Jewish community. By tearing apart fundamental interpersonal bonds it even deepened the disunity of the Jewish people. The realization of this fact seems to have been crucial for Buber's intellectual conversion, which prompted him to situate interpersonal relations at the heart of his philosophy. Another important factor of the disintegration of the double wave of nationalism was the Jewish disappointment with the development of German nationalism. In contrast to the early stages of the war when the Jews felt welcome in the fight for a common cause in the later stages the antisemitic element in German nationalism became more prominent. The Judenzählung was a clear sign that a substantial stream of German nationalism was hostile to the Jews. The lack of trust and reciprocity discouraged Jews from intensive support for German national ambitions.

Third, the analysis shows how a nationalist agenda prompts the creation of philosophical concepts that serve its objectives. This may be best exemplified with Buber's concept of a kinetic community. This concept is a philosophical expression of Buber's purely political call in the 1914 letter to Kohn for as massive participation of both the Germans and the Jews in the rising wave of nationalism as possible. The concept divides the nation into two groups. The decisive individuals authentically live out their convictions, passionately serve the fatherland and have a connection with the absolute. The individuals who merely pass by lack all these positive characteristics. They are useless in the dramatic situation in which the nation finds itself. They have failed the nation at a time when it needs them the most. With his enthusiastic descriptions of the decisive individuals Buber aims to motivate those who lack conviction or courage to join the war effort. He argues that the fight for the common cause is a way to self-fulfillment and even to an encounter with the divine. It was this idealization of the supporters of the nationalist cause and the dismissal of those who were not ready to endorse it that provoked Landauer's outrage. After Buber's conversion the dialogical conceptions provided a completely different point of departure that enabled a new approach to situations of conflict. 
The insights of the present analysis should be of value in different historical contexts. The formation of parallel waves of nationalism that interact with each other is a recurrent historical phenomenon. The examination of the intellectual positions of individual participants facilitates a more concrete understanding of these waves' dynamics. The analysis of the trajectory of Martin Buber's intellectual conversion has shed light on two waves of nationalism that originally strengthened each other but ultimately became incompatible.

\section{References}

Bizoň, M. (2017). Vzájomnost medzi Ja a Ty. Dialogická filozofia Martina Bubera [Mutuality between I and Thou. The Dialogical Philosophy of Martin Buber]. Trnava: UCM.

Brody, S. H. (2018). Martin Buber's Theopolitics. Bloomington, IN: Indiana University Press.

Buber, M. (1909). Ekstatische Konfessionen. Gesammelt von Martin Buber [Ecstatic confessions. Collected by Martin Buber]. Jena: Eugen Diederichs.

Buber, M. (1911): Die Erneuerung des Judentums [The renewal of Judaism]. In M. Buber, Drei Reden über das Judentum [Three speeches on Judaism] (pp. 57-102). Frankfurt am Main: Rütten \& Loening.

Buber, M. (1915). Bewegung. Aus einem Brief an einen Holländer [Movement. From a letter to a Dutchman]. Der Neue Merkur, 1(2), 489-92.

Buber, M. (1916a). Die Losung [The Watchword]. Der Jude, 1(1), 1-3.

Buber, M. (1916b). Der Geist des Orients und das Judentum [The spirit of the Orient and Judaism]. In M. Buber, Vom Geist des Judentums. Reden und Geleitworte [On the spirit of Judaism. Speeches and forewords] (pp. 9-48). Leipzig: Kurt Wolff Verlag.

Buber, M. (1916c). Judenzählung [The Jewish census]. Der Jude, 1(8), 564.

Buber, M. (1920). Unser Nationalismus [Our nationalism]. In M. Buber, Die jüdische Bewegung. Gesammelte Aufsätze und Ansprachen 1916-20. Zweite Folge [The Jewish movement. Collected essays and addresses 1916-20] (pp. 98-103). Berlin: Jüdischer Verlag.

Buber, M. (1921). Vom Geist des Judentums. Reden und Geleitworte [On the spirit of Judaism. Speeches and forewords]. Munich: Kurt Wolff.

Buber, M. (1923). Ich und $D u$ [I and Thou]. Leipzig: Insel-Verlag.

Buber, M. (1937). I and Thou (R. G. Smith, Trans.). Edinburgh: T. \& T. Clark.

Buber, M. (1972-75). Martin Buber. Briefwechsel aus sieben Jahrzehnten [Martin Buber. Correspondence from seven decades]. (Schaeder, G. Ed.). Heidelberg: Verlag Lambert Schneider, vols. 1-3.

Buber, M. (1984). Das dialogische Prinzip [The dialogical principle]. Heidelberg: Verlag Lambert Schneider.

Buber, M. (1996). The Letters of Martin Buber. A Life of Dialogue (N. N. Glatzer and P. Mendes-Flohr, Eds., R. and C. Winston and H. Zohn, Trans.). Syracuse, NY: Syracuse University Press.

Buber, M. (1993). Das Ende der deutsch-jüdischen Symbiose. [The end of the German-Jewish symbiosis]. In C. Schulte (Ed.), Deutschtum und Judentum. Ein Disput unter Juden aus Deutschland [Germans and Jews. A Debate among Jews from Germany] (pp. 150-3). Stuttgart: Reclam.

Buber, M. (2001ff.). Werkausgabe. [Collected Works]. Gütersloh: Gütersloher Verlagshaus, vols. 1-22.

Cohn, M. \& Buber, R. (Eds.) (1980). Martin Buber. Eine Bibliographie seiner Schriften. 1897-1978. [Martin Buber. A Bibligraphy of his Writings. 1897-1978]. Jerusalem et al.: The Magnes Press, Hebrew University. 
Friedman, M. (1991). Encounter on the Narrow Ridge: A Life of Martin Buber. New York: Paragon House.

Horwitz, R. (1978). Buber's Way to I and Thou. Heidelberg: Verlag Lambert Schneider.

Jay, Martin (2005). Songs of Experience. Berkeley and Los Angeles: University of California Press.

Mendes-Flohr, P. R. (1978). Von der Mystik zum Dialog. Martin Bubers geistige Entwicklung bis hin zu „Ich und Du.” [From Mysticism to Dialogue. Martin Buber's Spiritual Development up to „I and Thou"]. Königstein/Ts.: Jüdischer Verlag.

Mendes-Flohr, P. (2006). Martin Buber as a Habsburg Intellectual. In R. Gross and Y. Weiss (Eds.), Jüdische Geschichte als Allgemeine Geschichte (pp. 13-29). Göttingen: Vandenhoeck \& Ruprecht.

Šajda, P. (2013). Buberov spor s Kierkegaardom. O vzíahu náboženstva $k$ etike a politike. [Buber's polemic with Kierkegaard. On the relationship of religion to ethics and politics]. Bratislava: Kalligram.

Shapira, A. (1999). Hope for Our Time. Key Trends in the Thought of Martin Buber (Green, J. M., Trans.) Albany, NY: State University of New York Press.

Department of Philosophy

Faculty of Arts, Trnava University

Hornopotočná 23

91701 Trnava

Slovakia

Email: filosajd@savba.sk 